07-089

\title{
Self-regulatory Institutions for Solving Environmental Problems: Perspectives and Contributions from the Management Literature
}

\author{
Andrew King \\ Michael W. Toffel
}




\title{
Self-regulatory Institutions for Solving Environmental Problems: Perspectives and Contributions from the Management Literature
}

\author{
ANDREW KING \\ Tuck School of Business at Dartmouth College \\ 202 Chase Hall \\ Hanover, NH 03755 \\ Office: 603-646-9185 \\ Cell: 603-359-0369 \\ andrew.a.king@dartmouth.edu
}

\author{
MICHAEL W. TOFFEL \\ Harvard Business School \\ Soldiers Field \\ Boston, MA 02163 \\ Office: 617-384-8043 \\ mtoffel@hbs.edu
}

July 2007

\begin{abstract}
Scholars of management have long considered how institutions can help resolve market imperfections and thereby improve human welfare. Most previous research has emphasized the use of for-profit firms. Such institutions cannot effectively address many environmental problems, however, because environmental problems often transcend firm boundaries. As a result, management scholars have begun to explore the use of more distributed institutional forms. In this article, we review the emerging scholarship on the formation and function of self-regulatory institutions.
\end{abstract}




\section{INTRODUCTION}

What role can business managers play in finding solutions to environmental problems? For many years, the business management literature proposed that managers could help their firms discover win-win opportunities that protect the environment while simultaneously increasing profits (Porter \& van der Linde, 1995; Hart, 1995). This is an attractive suggestion, for it implies that environmental protection can be accomplished with little pain, and that environmental problems are caused not by defects in our institutions but by failures in our insight or perception.

The literature on when it might "pay to be green" has advanced our understanding of how and when firms achieve sustained competitive advantage. What this literature has failed to do, however, is demonstrate that "win-win" opportunities will be sufficient to bring about meaningful environmental improvements. "I used to think that all we needed was a few managers to 'get it,"” remarked Matt Arnold, founder of the Management Institute for the Environment and Business. "Now, I think that the problem goes much deeper." ${ }^{1}$

If managers who "get it" cannot find ways to profitably protect the environment, then, given the magnitude of today's environmental problems (UNEP 2002; Worldwatch Institute 2006), the rules of competition must be changed to make environmental responsibility more profitable. North (1991: 97) defines these rules, which he terms "institutions," as the "humanly devised constraints that structure political, economic, and social interaction.” Institutions come in many forms: formal or informal, private or public, centralized or decentralized (North, 1981; Ingram \& Clay, 2000). For-profit firms, the subject of most management research, are examples

\footnotetext{
${ }^{1}$ Personal communication with Andrew King, March 2, 2004.
} 
of private, centralized institutions. They are categorized as private because participants can choose whether to opt in or out. They are defined as centralized because they usually include an authority that sets and enforces internal rules.

When and why economic tasks are organized within a firm hierarchy as opposed to within markets (i.e., exchange between firms) is a classic and enduring theme in the management literature. The "Theory of the Firm" proposes that transactions are internalized in firms when particular features (e.g., uncertainty or specificity) are problematic with respect to market exchange, and the magnitude of the problems exceeds the disadvantages of organizing within firms (e.g., bureaucracy costs, “low powered” incentives) (Coase, 1937; Williamson, 1985).

From its earliest days, this literature has had direct relevance to environmental problems. When the cost of negotiating and enforcing a mutually beneficial outcome is low, the theory goes, institutional controls are not needed (Coase, 1960; Stigler, 1989). Those who desire to protect a natural (environmental) resource can directly negotiate improvements with those who might harm it. For example, in the early 1990s, the environmental non-profit Environmental Defense Fund worked with MacDonald's to help them develop and adopt packaging that caused less pollution.

When the costs of negotiating and enforcing such solutions are high, however, a single firm might take control of both the resource and the potential polluter to facilitate a better outcome (Coase, 1937; 1960). For example, to help manage land as both a source of timber and a preserve for endangered species, the Conservation Fund and International Paper set up a new independent corporation to manage an important tract of land in Texas.

When neither negotiation nor firm control is feasible, governments can provide regulatory solutions to environmental problems. For many environmental problems, however, 
government lacks the will or authority to develop a regulatory solution. Pollution and invasive species do not stop at regulatory boundaries, much of our planet lies outside the territorial waters of any nation, and the earth's atmosphere is a commons shared by all. In a handful of instances, such as the Montreal Protocol regulation of chlorofluorocarbon (CFC) emissions, governments have coordinated regulatory solutions to important environmental problems. But despite a plethora of trans-boundary and global environmental problems, stringent, rigorously enforced international conventions are the exception rather than the rule. Can management scholarship provide insight into how firms might help resolve important environmental problems that lie within or span political and regulatory boundaries?

In the absence of government regulation, solutions to environmental problems might require that actors "self-regulate." Scholars have long been skeptical that, unmediated by a central authority, actors would be able to agree upon and enforce better rules of competition. Scholars from William Forster Lloyd (1833) to Garrett Hardin (1968) have employed "the tragedy of the commons" as a powerful metaphor for the problems inherent in self-regulation. Although each actor shares in the benefits derived from the conservation of common resources, each actor also directly profits by consuming more of the resource. Thus, according to Hardin (1968), "the inherent logic" of any commonly held resource "remorselessly" leads to ruin. The logic of commons problems can be extended to self-regulation of any shared problem. As Schlager (2002: 804) observes, the mutual benefits afforded by self-regulation generates a new, “second order”, commons problem:

By cooperating and adopting sets of rules that coordinate use of and contributions to a common pool resource, appropriators can solve the first-order dilemmas. However, the sets of rules themselves may be thought of as public goods. Once provided, they benefit all appropriators, whether or not all appropriators contributed to their creation. Appropriators face incentives to free-ride off of the efforts of others who attempt to resolve the first-order dilemmas. 
Such a history of skepticism would seem to imply that self-regulatory institutions should be rare, but empirical observation suggests otherwise. Self-regulatory institutions exist in industries as diverse as accounting, electronics, computer software, agriculture, and banking (Furger, 1997). Some, like the Motion Picture Association of America's movie ratings system and the chemical industry’s Responsible Care program, are well funded and visible.

Inspired by scholars like Elinor Ostrom, Robert Keohane, and Oran Young, management scholars have begun to investigate prominent examples of self-regulatory institutions, with an emphasis on those that address environmental problems. ${ }^{2}$ Early work in the business and environment literature sought simply to categorize the numerous sponsors of self-regulatory institutions including corporations, trade associations, international organizations, and other stakeholders (c.f. Nash \& Ehrenfeld, 1997). Some, like the Marine Stewardship Council, were formed through the collaboration of corporations and stakeholder groups (Reinhardt, 2000). Others were created by international organizations like the International Organization for Standardization (ISO). Programs developed by regulators, industry associations, and other nongovernmental organizations feature "almost equivalent program designs [regarding] environmental, administrative and conformance requirements” (Darnall \& Carmin, 2005: 84). These sponsors often seek and incorporate input from an array of stakeholders to enhance the legitimacy of the self-regulating institution (Carmin, Darnall, \& Mil-Homens, 2003).

Research on environmental self-regulatory institutions has both contributed to and drawn inspiration from research on self-regulation of other types of problems. Studies of knowledge sharing organizations (Furman \& Stern, 2006), developer communities (Harhoff \& Mayrhofer, 2007), open-source software (Alexy \& Henkel, 2007), and interconnectivity standards (Farrell \&

\footnotetext{
${ }^{2}$ For excellent reviews of the theoretical and empirical literature on government voluntary environmental programs, see Khanna (2001) and Lyon and Maxwell (2007).
} 
Simcoe, 2007) are, in concert with research on self-regulation of environmental problems, advancing our understanding of self-regulation.

In this chapter, we review the growing literature on self-regulatory institutions for solving environmental problems. Our focus is on private institutions, which means that firms and other actors choose whether or not to participate. Many are decentralized, lacking a central authority that can administer sanctions. Scholars have examined the circumstances under which selfregulatory institutions that exhibit these characteristics arise, how they gain power and participants, and whether they are effective at influencing behavior.

\section{DRIVERS OF SELF-REGULATION IN MODERN INDUSTRIES: WHEN DO SELF-REGULATORY INSTITUTIONS ARISE?}

Many management scholars have been influenced by Elinor Ostrom’s path breaking work on self-regulation of commonly held water, forests, and fishery resources (Ostrom, 1990; Ostrom, Garner, and Walker, 1994). Yet, the common pool resource problems Ostrom studies are not immediately apparent in many modern industrial settings (c.f. Khanna, 2001). What might drive self-regulation in these industries? Some authors have tried to explain the emergence of self-regulatory institutions in industries that do not share a common physical resource by arguing that common problems can arise from interaction with other institutions or institutional actors. Other scholars have suggested that self-regulation might be a response to market inefficiencies caused by asymmetric information.

\section{Common sanctions}

Several scholars have argued that blunt application of force by governments or stakeholders can create a shared fate that encourages collective action (Dawson \& Segerson, 
2005; King, Lenox, \& Barnett, 2002). For example, if the decision to regulate an industry is determined by its collective performance, a classic social dilemma is created in which individual firms want others to improve but have little incentive to do so themselves (Dawson \& Segerson, 2005; Maxwell, Lyon, \& Hackett, 2000). A risk of common sanctions can also be occasioned by consumers' or activists' inability to differentiate performance among firms. For example, the Earth Island Institute initiated a boycott of all albacore tuna even though some companies sourced from locations in which porpoises were not put at risk by tuna fishing (Reinhardt \& Vietor, 1996).

A number of studies have quantified this industry commons problem by investigating how the behavior of one firm might influence the perceived value of another firm in the industry. Research has demonstrated, for example, that an accident at one firm can lower stock prices of other firms in its industry (Hill \& Schneeweis, 1983), and that recalls of pharmaceuticals and automobiles reduced the value of competitor firms in those industries (Jarrell \& Peltzman, 1985). The magnitude of this "sanction commons" problem increases the more similar the firms are (Blacconiere \& Patten, 1994).

Dawson and Segerson (2005) observe that the risk of common sanctions can drive the formation of self-regulatory institutions by helping to coordinate collective improvement that may forestall government regulation. Hoffman (1999: 366) notes that major accidents and spills as well as exogenous events such as the publication of Rachel Carson's Silent Spring can change the perception of industries "suddenly and unpredictably." Hoffman and Ocasio (2001) argue that such events have greater impact when they violate existing norms and frames. Indeed, many prominent environmental self-regulatory institutions were born in the wake of accidents or 
controversies that raised the threat of common regulatory or stakeholder sanctions. ${ }^{3}$ The threat of more stringent regulation following the Three Mile Island accident, for example, prompted nuclear power industry executives to create the Institute of Nuclear Power Operation, a "private regulatory bureaucracy” charged to "develop standards, conduct inspections, and investigate accidents” (Rees, 1997: 478). Similarly, the Exxon Valdez tanker accident encouraged the development by the petroleum industry of the "Valdez Principles," later renamed the CERES Principles (Nash \& Ehrenfeld, 1997); a smuggled video of dolphins being caught and tortured on tuna boats provided impetus for the creation of the "dolphin safe" certification system (Reinhardt, 2000); and the chemical industry developed its Responsible Care program following a deadly accident in Bhopal, India that spurred calls for increased regulation of chemical manufacturers (Gunningham, 1995). With regard to the latter incident, Nash and Ehrenfeld (1997: 498) described the threatened common sanction as follows: "The Bhopal disaster crystallized the public's image of the chemical industry as indifferent to environmental and safety concerns and as sealed off from public scrutiny” (emphasis added).

\section{Asymmetric information}

Since Akerlof (1970), scholars have recognized that asymmetric information can cause a collective problem by creating an inefficient "market for lemons" in which only low quality products can be sold. Such inefficient markets are common causes of environmental problems because the environmental attributes of goods and services are usually hidden. For example,

\footnotetext{
${ }^{3}$ An example of another domain in which a self-regulatory institutions emerged in response to the threat of common sanctions is the Classification and Ratings Board created by the Motion Picture Association of American "in response to a national cry for some kind of regulation of film content” (http://www.mpaa.org/Ratings history1.asp, accessed April 16, 2006). Similarly, prompted by the perceived ongoing regulatory threat posed by Congress and the Federal Trade Commission, the three major alcoholic beverage industry associations operate under voluntary advertising codes that include guidelines for preventing the marketing of alcohol to minors. When the Distilled Spirits Council announced that it would end its 50-year-old voluntary ban on television and radio advertising, the beer and wine industries were concerned that the move would lead to more regulation of all alcohol marketing (Beaver, 1997).
} 
customers cannot determine by inspection whether or not the cotton in a pair of trousers was grown in an organic manner or a pound of coffee beans was grown under a natural forest canopy. Solving asymmetric information problems can improve the welfare of both producer and consumer. When an unobserved quality has an impact on the environment, solutions to inefficiencies caused by asymmetric information can also provide environmental benefits.

A commonly proposed solution to the problem of asymmetric information is for the party with superior information to make visible expenditures that would only be rational if its claims of superior quality were truthful. Signaling models suggest that, on some hidden quality dimension, participants should perform better than non-participants. ${ }^{4}$ A classic example is expenditures on brand advertising; such investments are thought to be profitable only to firms with higher quality products that will generate sufficient rents to cover the advertising expenditures.

Signaling is particularly important in experience goods (for which some important attributes are unobservable before consumption) and credence goods (for which some important attributes remain unobservable even after consumption). Environmental goods and services are often credence goods. Consider the two examples above: even after purchasing and "consuming” the trousers and coffee, the consumer will never be able to directly ascertain whether the cotton was organic or the coffee "shade-grown”. In such cases, it might be possible to resolve information asymmetry only by creating institutions that dispatch knowledgeable outsiders to inspect and certify characteristics that are unobservable at the point of sale (Darnall \& Carmin, 2005). Scholars have proposed that self-regulatory institutions that require changes

\footnotetext{
${ }^{4}$ Below, we review the empirical literature that tests the signaling story by examining the extent to which environmental self-regulating institutions (a) attract participants that exhibit superior ex ante environmental performance, or (b) lead participants to develop superior environmental performance.
} 
in behavior as well as certification of these changes help firms communicate unobserved attributes of their products or processes to customers (King, Lenox, \& Barnett, 2002).

\section{SOURCES OF POWER: WHY DO FIRMS PARTICIPATE IN SELF-REGULATORY INSTITUTIONS?}

How environmental self-regulatory institutions gain the power to influence behavior has been the subject of much research. Why do organizations follow their rules rather than free-ride? Scholars' responses have emphasized two broadly differing perspectives: institutionalization and strategic interests. According to the former perspective, an institutions' power derives from becoming "institutionalized" in social settings. Agent cognition and choice are thereby constrained, inhibiting opportunistic behavior. The latter perspective presumes organizations to continue to have the freedom to behave opportunistically, but to be constrained by self-interest from doing so. Management scholars have explored these two perspectives by way of investigating the factors that lead firms to participate in self-regulatory institutions.

\section{Institutionalization}

From the perspective of institutional theory, self-regulatory institutions represent preconscious or post-conscious constraints on strategic behavior. Pre-conscious constraints occur because institutions include taken-for-granted elements that create powerful schema or frames for decision-making (Berger \& Luckmann, 1966). These elements influence what decision makers perceive and what choices they consider. Post-conscious constraints "directly or indirectly divert design adoption away from the proposed dynamic in transaction cost economics (i.e., comparative efficiency) and toward the dynamic of legitimacy” (Roberts \& Greenwood, 1997: 355). Thus, institutionalism emphasizes "factors which make actors unlikely to recognize 
or act on their interests" and that cause "actors who do recognize and try to act on their interests to be unable to do so effectively" (DiMaggio, 1988: 5). Hoffman (1999) argues, for example, that in the chemical industry frames of perception evolved as metaphors of pollution shifted from being a regulatory compliance problem to a feature of corporate strategy and profitability. As shared frames of perception changed, responses included more strategic considerations, and firm interaction with stakeholders assumed new forms.

A number of authors searching for evidence of the pre and post conscious constraints applied by self-regulatory institutions have investigated whether cognitive, normative, or coercive pressures lead organizations to participate in self-regulatory institutions. Delmas (2002: 91) concludes they do, as she finds that "regulatory, normative, and cognitive aspects of a country's institutional environment greatly impact the costs and potential benefits of the ISO 14001 [Environmental Management System] standard and therefore explain the differences in adoption across countries.”

Several studies have found that coercive pressures influence organizations to adopt selfregulation programs. Empirical studies have found firms' decisions to adopt the ISO 14001 environmental standard to be influenced by, for example, coercive pressure from local wealthy stakeholders, civil society, and customers in Europe and Japan (Christmann \& Taylor, 2001; Neumayer \& Perkins, 2004). Other authors have found that government pressure or support influences firms to participate in self-regulatory institutions (Chan \& Wong, 2006; Rivera, 2004; Rivera \& de Leon, 2004; Rivera, De Leon, \& Koerber, 2006; Shin, 2005; Short \& Toffel, 2007).

Researchers have also found evidence that normative pressure causes firms that participate in one self-regulatory program to participate in others. For example, several researchers found that firms that had adopted the ISO 9000 Quality Management System 
Standard were more likely to adopt the ISO 14001 Environmental Management System Standard as well (Corbett \& Kirsch, 2004; King \& Lenox, 2001; Marimon Viadiu, Casadesús Fa, \& Heras Saizarbitoria, 2006). ${ }^{5}$

Recent work has begun developing a contingency theory of institutionalism that explores why organizations subjected to common institutional pressures nonetheless participate in different self-regulating institutions. Hoffman (2001: 138) argues that such decisions reflect the interaction between institutional pressures and internal organizational factors such as “organizational structure and culture.” In their empirical analysis, Delmas and Toffel (2007) find evidence of such interactions. They find that organizations whose corporate marketing departments are influential on environmental matters tend to adopt ISO 14001 to distinguish their environmental status to customers. On the other hand, those with more influential legal departments are more likely to adopt government voluntary environmental programs to distinguish themselves to regulators.

\section{Strategic choice}

The strategic choice perspective maintains, in sharp contrast to the institutionalism perspective, that self-regulatory institutions represent nothing more than the outcome of strategic interactions. Drawing on the theory of cartels and clubs, scholars have developed many formal models of self-regulatory institutions (Barrett, 1994; Dawson \& Segerson, 2005; Potoski \& Prakash, 2005b). In most of these models, actors propose rules for the group to which the group responds by deciding whether to participate and how to behave. In making these decisions, each actor considers how all others will behave, and how different options will influence the decisions of other actors. By considering this process in detail, scholars identify one or more equilibrium

\footnotetext{
${ }^{5}$ For an exception, see Melnyk, Sroufe, \& Calantone (2003).
} 
where each actor will be making her best decision (given what she expects everyone else to do). The "institution" as it is observed in business practice is the expression of this equilibrium.

To empirically investigate the extent to which strategic opportunism drives firms' decision of whether to participate in self-regulation institutions, several authors have looked for standard signs of opportunism. These authors have predicted that programs without strict entry rules or robust monitoring systems will fall victim to "adverse selection."

For example, participation in the chemical industry’s Responsible Care program required firms to sign a paper "commitment” to adopt the program’s principles and practices. Launched without any other entry requirement, without any required objectives or timetables, and with no monitoring system, the program suffered from adverse selection: participating firms tended to pollute more than comparable firms in the same industry (King \& Lenox, 2000). Studies of other self-regulatory programs with weak enforcement have also exposed telltale signs of strategic opportunism. For example, Rivera and De Leon (2005) found no evidence of superior environmental performance on the part of participants in a hotel "eco-label" program in Costa Rica. They also found the performance of participants in the self-regulatory Sustainable Slopes program for ski areas to be inferior to that of non-members (Rivera \& de Leon, 2004).

Overlapping oversight by different institutional actors in the maritime shipping industry promoted monitoring of conformance to that industry's self-regulatory safety institutions, according to Furger (1997), who explains that sanctions and rewards from insurance companies provided incentives to conform to agreed upon standards. Self-regulatory institutions lost the power to control behavior, he observes, when market pressure and new industry entrants eroded these conditions. 
The ISO 14001 Environmental Management System Standard is one of a handful of selfregulatory institutions that impose a robust entry requirement, namely, third-party certification, as a condition of participation. A number of studies have suggested that organizations adopt ISO 14001 to signal their superior environmental management or performance. King, Lenox, and Terlaak (2005) find that firms obtain ISO 14001 certification to overcome information asymmetries that tend to be particularly acute when dealing with distant or foreign exchange partners. Welch, Mori, and Aoyagi-Usui (2002) find that decentralized organizations are more likely to adopt ISO 14001, which might imply that facility managers use adoption to signal to corporate officers the (unobservable) quality of facility processes. They also find that adopters are subject to more local regulation, which might imply that some organizations use adoption to signal to regulators their serious commitment to compliance.. The extent to which these signals should be viewed as credible remains unclear: one empirical study finds that, on average, organizations that adopted ISO 14001 exhibited superior environmental performance (Toffel, 2006); another finds no distinction between adopters and non-adopters (King, Lenox, \& Terlaak, 2005).

Others have looked beyond stringent monitoring to the threat of sanctions to mitigate opportunism. Lenox and Nash (2003), for example, argue that self-regulatory institutions that have demonstrated a serious commitment to expel non-compliant members are less likely to suffer from adverse selection. Their empirical analysis found that a forestry trade association's self-regulation program, which featured a credible threat of expulsion, attracted a disproportionate number of participants that exhibited superior environmental performance ex ante, but no evidence that a similar provision of a chemical distribution association was effective in such screening. 


\section{Integrating the two perspectives}

A few researchers have begun to integrate the institutional and strategic perspectives. Jiang and Bansal (2003: 1047), for example, make an important distinction between participation in the underlying technical aspects of self-regulatory programs and the use of symbolic association with such programs. They find that "institutional pressures and market demand often motivate firms to adopt the technical aspects of programs” and that the tendency to seek visible association with the institution (e.g., by obtaining third-party certification) is driven by "task visibility and environmental impact opacity.” King, Lenox, and Terlaak’s (2005) empirical test of this idea in a larger setting corroborates these results. They find that different factors explained the propensity to adopt versus certify an environmental management system. Pressure from waste handlers encouraged adoption of the management system, while the need to communicate improvement to distant or foreign product buyers tended to cause certification.

\section{EMPIRICAL EVIDENCE OF POWER: ASSESSING THE EFFECTIVENESS OF SELF-REGULATING INSTITUTIONS}

As the long-standing skepticism about the potential for self-regulation has given way to a sense of possibility, scholars have begun to explore when and where such institutions can be effective. Early work expressed excitement and optimism that these institutions represented a general advancement in human attitudes and social organization. For example, Nash and Ehrenfeld (1997: 525) concluded a major review of self-regulation programs noting:

The human tragedy of Bhopal and the environmental disaster of the Exxon Valdez oil spill intensified public pressure on industry to change not just its practices but its underlying values.... This review suggests that codes have culture-changing potential. Codes include elements that may be establishing a closer connection in 
people's minds between their activities and the natural world. Codes may also be increasing managers' sense of responsibility to surrounding communities.

In the ensuing decade, a small but growing literature has examined the extent to which self-regulatory institutions are actually delivering on their promise to mitigate environmental damage. We review several program evaluations that investigate the implications of participating in particular self-regulatory institutions. These studies have focused on two types of dependent variables: process metrics such as the adoption of particular management practices; and outcome metrics such as pollution levels and environmental regulatory compliance. Researchers have focused on monitoring and sanctions as potential mechanisms for bolstering program effectiveness.

Early evaluations focused on the Responsible Care program, which lacked implementation requirements (it required only a "commitment”) as well as monitoring and sanctions mechanisms. Empirical researchers found that participation provided "a poor indicator that any particular standard practices will be followed" (Howard, Nash, \& Ehrenfeld, 2000). Worse, the program apparently suffered from "moral hazard," as participating firms experienced less environmental performance improvement than non-participants (King \& Lenox, 2000). Similarly, Rivera, de Leon, and Koerber's (2006) evaluation of Sustainable Slopes, another selfregulatory institution that lacks independent monitoring and enforcement provisions, found that even five years after its inception participants still had not overcome their initial deficit in environmental performance relative to non-participants. ${ }^{6}$

In contrast, evaluations of self-regulatory institutions that feature independent monitoring have found evidence that suggests they facilitate performance improvement. Recent studies have found, for example, that plants that became certified to ISO 14001 subsequently improved their

\footnotetext{
${ }^{6}$ According to the US EPA, the program has "nonbinding obligations" and "no consequences...if resorts do not employ suggested actions or do not report annually" (Rivera, de Leon, \& Koerber, 2006: 202-203).
} 
environmental regulatory compliance (Dasgupta, Hettige, \& Wheeler, 2000; Potoski \& Prakash, 2005b) and reduced their pollution levels faster than plants that had not adopted the standard (Potoski \& Prakash, 2005a; Toffel, 2006). Another empirical evaluation found that plants that were certified to the ISO 9000 Quality Management System Standard subsequently reduced waste to a greater extent than did non-adopters (King \& Lenox, 2001). ${ }^{7}$

Scholars have noted that some self-regulating institutions bolster their internal monitoring and enforcement provisions by operating in the shadow of the regulator (Short \& Toffel, 2007; Rees, 1994). For example, Rees (1994) notes that the Institute of Nuclear Power Operations, a self-regulating institution created by the nuclear power industry, could support its internal sanctions with a threat to reveal non-compliance to the Nuclear Regulatory Commission. Indeed, Rees (1994) attributes the success of self-regulation among nuclear power plant operators to their ability to use the threat of sanctions from government regulators to discourage free riding. Furger (1997) argues in a similar vein that self-regulatory institutions in maritime shipping could enforce compliance by revealing information to insurance companies or regulators. Only a few of the many voluntary environmental programs developed by government agencies contain provisions that impose risks on participants that fail to obey the rules (Short \& Toffel, 2007).

Signaling models of self-regulatory institutions also suggest that participants should benefit financially. Because ISO 14001 has been adopted by relatively few facilities (at least in the United States), scholars have turned their attention to its close cousin, the ISO 9000 Quality Management System Standard. Terlaak and King’s (2006) finding that certification is associated with a moderate increase in production suggests that it helps to attract marginal customers, and

\footnotetext{
${ }^{7}$ For an exception, see Terlaak and King (2006).
} 
Corbett, Montes-Sancho, and Kirsch (2005) find ISO 9000 certification to be associated with substantially higher financial returns.

Equilibrium models of cartel-like self-regulating institutions are much harder to test. Depending on the precise structure of these models, multiple equilibria may exist and different static hypotheses can be generated. In general, however, these models suggest that (a) participants should benefit from participating, (b) non-participants should benefit from not participating, and (c) the institution should provide some welfare benefit to the participants (Barrett, 1994; Dutta \& Radner, 2004). These models usually suggest, moreover, that the greatest gains should accrue to the non-participants because as free-riders they appropriate the value without incurring any of the cost of the program. These expectations have been best explored in connection with the Responsible Care program. Lenox (2006) finds that the program's creation generated dramatic financial benefits to most firms in the industry, and that non-participating firms benefited considerably more. Barnett and King (2006) find that the devastating chemical accident in Bhopal, India created a common sensitivity to accidents such that an event at one firm would depress the stock price of another. They find evidence that Responsible Care reduced this tendency, but benefited all firms in the industry, not just participants.

A theoretical problem for much of the research that uses economic models to explore self-regulatory institutions is that the evidence of environmental and financial consequences often seems to yield contradictory insights. For example, scholars have tended to argue that the Responsible Care program is a means of forestalling government regulation (King \& Lenox, 2000; Rees, 1997). In that case, participants should improve their environmental performance because the program helps them cooperate to prevent regulation. But as discussed earlier, the 
opposite seems to be true: the rate at which participants reduced their emissions slowed after joining the program. Financial benefits delivered by such a program might reflect the credulity of stakeholders that ascribe meaning to a program without a rational basis. Alternatively, studies that find adverse selection and moral hazard might have missed important variables of interest to stakeholders (e.g., accident prevention) upon which participants did improve.

Another problem for the literature is that the design of some self-regulatory institutions seems to provide conflicting incentives. Darnall and Carmin (2005) find that variability in the rules and mechanisms employed by self-regulatory institutions confuses the interpretation of participation. The great variation in a programs' objects, design concepts, and rules lead them to suggest that stakeholders (or researchers) who lump programs together will tend to respond inefficiently to them. Terlaak (2007) observes that some programs actually contain conflicting design objectives, such as providing both useful best practice guidelines and a means of distinguishing high and low performing firms. The problem, she notes, is that the worst firms stand to gain the most from the guidelines, which can lead to adverse selection. Such conflicting objectives, she reflects, can undermine the ability of such programs to identify organizations with superior hidden attributes.

\section{SUMMARY AND FUTURE DIRECTIONS}

Until recently, management research on environmental problems emphasized the search for greater efficiency within firm hierarchies. This research agenda has begun to change in the light of growing evidence of limits to win-win opportunities and voids in state regulation. Management scholars are increasingly turning their attention to how firms can fill such voids 
with self-regulatory institutions. In this chapter, we reviewed the emerging management literature on these institutions.

For readers interested in practical solutions to environmental problems, the research presented in this chapter suggests that self-regulation should be taken seriously. Many firms have voted with their feet and joined prominent examples of self-regulatory institutions. Managers in these firms appear to believe that participating in these institutions will help them solve real problems. Initial empirical research suggests that some of these institutions might, indeed, help firms reduce market inefficiencies. Some appear to reduce asymmetries in information, others to facilitate coordinated investment in solutions to common problems. In the aggregate, the research reviewed reveals a world not of inevitable tragedy but of possibility.

But the research also reveals a need for caution in predicting the effect of self-regulatory institutions. These institutions derive their meaning and power from the distributed interpretations and choices of numerous actors. The intentions of the original sponsor may be modified or subverted, and their economic meaning may change over time. Some self-regulatory institutions may be little more than smoke screens deployed to prevent more effective stakeholder or government action. Others may provide incentives for real environmental improvement.

For readers interested in extending management theory, the research reviewed here demonstrates a need for more realistic models of human behavior. Neither under-socialized models of actors with unlimited strategic insight nor over-socialized models of actors with little choice appear sufficient to explain observed behavior. The pursuit of individual gain plays a central role in the creation of these institutions and determines how they are understood and used. Yet the institutions do not appear to be the product of fully rational actors. Some observed 
behavior appears to be contradictory and inconsistent; outcomes appear to be off equilibrium paths; and the meaning of these institutions becomes both larger and richer than justified by purely economic rationale.

We are not suggesting that there is no longer a need for models of institutions that assume fully rational actors. Such models will continue to provide a valuable benchmark for theoretical and empirical study. We believe, however, that the research discussed in this chapter reveals that the most useful theories might assume that actors have limited ability to anticipate consequences or plan complex strategies and derive predictions of institutional function from this basis.

We expect that models of self-regulatory institutions based on actors with what Ostrom (1998) terms "thin rationality" will pay more attention to the history of the institution. The actors observed in our empirical analysis could not predict how institutions would be used, and may even hold inconsistent goals. Participants could not always estimate costs and benefits either in the present or in the future. We look to models based on actors with limited cognition to help explain observed regularities in self-regulation. Why, for example, do sponsors often believe that the institutions they help create will play a different role than the one they eventually take? Why did several self-regulatory institutions evolve from more lenient to more exacting forms?

We also recognize that the institutions reviewed here do not operate in isolation. All operate within the context of larger cultures or national regulations. Models that incorporate agents with limited rationality might help to explain how institutions interact. We have observed that some self-regulatory institutions are given social or political authority they do not appear to deserve. We wonder whether cultural traditions and perceptions might explain why firms are sometimes rewarded for participating in programs that neither improve their performance nor reveal hidden attributes. 
Empirically testing new theories of self-regulation will be a difficult task. ${ }^{8}$ Many of the studies documented in this chapter are case examples, including numerous organizations but exploring only a single self-regulatory institution. We believe that such case research is important and should continue, but that other research methods should be exploited as well. Experimental research, in particular, may hold great promise. Computer systems support testing of strategic interaction in varying competitive environments, enabling researchers to adjust regulatory and competitive conditions to explore when self-regulation occurs and where it functions best.

Many more questions can be formulated from the literature reviewed in this article. For example, to date few researchers have leveraged the parallels and potential synergies between the self-regulating institutions literature and research on eco-labeling (e.g., Mattoo \& Singh, 1994; Caswell, 1998). This is particularly surprising given that many eco-labeling schemes are themselves self-regulating institutions and have been subjected to a growing number of empirical evaluations (e.g., Tejeda-Cruz \& Sutherland, 2004; Teisl, Roe, \& Hicks, 2002). We believe that understanding can be advanced by analysis and empirical investigation of related institutional forms and empirical settings. For example, open-source software also includes a type of commons problem. Understanding how these problems are resolved will help clarify both the universal and unique aspects of using self-regulation to solve environmental problems.

Perhaps the most important contribution of the reviewed literature is that it provides precedence for asking such questions within the field of management. Consideration of selfregulatory institutions is growing rapidly. Many of the scholars now studying self-regulation of standards, knowledge sharing, and open-source software development are drawing on the

\footnotetext{
${ }^{8}$ See Bennear and Coglianese (2006) for a review of empirical methods of program evaluation in the context of environmental self-regulatory institutions including government voluntary environmental agreements.
} 
reviewed literature for inspiration in framing research questions and methods. We hope the interplay among these studies will change the "state of play" within the management field and expand our understanding of how firms can create effective institutions for protecting the natural environment. 


\section{REFERENCES}

Akerlof, G.A. 1970. Market for lemons: Quality uncertainty and market mechanism. Quarterly Journal of Economics, 84(3): 488-500.

Alexy, O. \& Henkel, J. 2007. Promoting the penguin: Who is advocating open source software in commercial settings? Paper presented at the Second Annual Conference on Institutional Foundations for Industry Self-Regulation, Harvard Business School, Boston, MA.

Barnett, M.L., \& King, A.A. 2006. Good fences make good neighbors: An institutional explanation of industry self-regulation. Paper presented at the Academy of Management Best Paper Proceedings, Atlanta, GA.

Barrett, S. 1994. Self-enforcing international environmental agreements. Oxford Economic Papers-New Series, 46: 878-894.

Beaver, William. 1997. What to do about alcohol advertising. Business Horizons, 40 (4): 87-91.

Bennear, L.S., \& Coglianese, C. 2006. Program evaluation of environmental policies: Toward evidence-based decision making. In C. Coglianese \& J. Nash (eds.), Beyond Compliance: Business Decision Making and the US EPA's Performance Track Program: 115-130. Cambridge, MA: Harvard University John F. Kennedy School of Government.

Berger, P., \& Luckmann, T. 1966. The Social Construction of Reality. New York: Doubleday.

Blacconiere, W.G., \& Patten, D.M. 1994. Environmental disclosures, regulatory costs, and changes in firm value. Journal of Accounting \& Economics, 18(3): 357-377. 
Carmin, J., Darnall, N., \& Mil-Homens, J. 2003. Stakeholder involvement in the design of U.S. voluntary environmental initiatives: Does sponsorship matter? Policy Studies Journal, 31(4): 527-543.

Caswell, J.A. 1998. How labeling of safety and process attributes affects markets for food. Agricultural and Resource Economics Review, 27: 151-158.

Chan, E.S.W., \& Wong, S.C.K. 2006. Motivations for ISO 14001 in the hotel industry. Tourism Management, 27(3): 481-492.

Christmann, P., \& Taylor, G. 2001. Globalization and the environment: Determinants of firm self-regulation in China. Journal of International Business Studies, 32(3): 439-458.

Coase, R.H. 1937. The nature of the firm. Economica, 4(16): 386-405.

Coase, R.H. 1960. The problem of social cost. Journal of Law \& Economics, 3: 1-44.

Corbett, C.J., \& Kirsch, D.A. 2004. Response to "Revisiting ISO 14000 diffusion: A new 'look' at the drivers of certification." Production and Operations Management, 13(3): 268-271.

Corbett, C.J., Montes-Sancho, M.J., \& Kirsch, D.A. 2005. The financial impact of ISO 9000 certification in the United States: An empirical analysis. Management Science, 51(7): 1046-1059.

Dasgupta, S., Hettige, H., \& Wheeler, D. 2000. What improves environmental compliance? Evidence from Mexican industry. Journal of Environmental Economics and Management, 39(1): 39-66.

Darnall, N., \& Carmin, J. 2005. Greener and cleaner? The signaling accuracy of US voluntary environmental programs. Policy Sciences, 38(2-3): 71-90. 
Dawson, N.L., \& Segerson, K. 2005. Voluntary environmental agreements with industries: Participation incentives with industry-wide targets. Working Paper, University of Connecticut.

Delmas, M.A. 2002. The diffusion of environmental management standards in Europe and in the United States: An institutional perspective. Policy Sciences, 35(1): 91-119.

Delmas, M.A,. \& Toffel, M.W. 2007. Organizational response to environmental demands: Opening the black box . Working Paper, Harvard Business School.

DiMaggio, P.J. 1988. Interest and agency in institutional theory. In Lynn G. Zucker (ed.), Institutional Patterns and Organizations: Culture and Environment: 3-21. Cambridge, MA: Ballinger.

Dutta, P.K., \& Radner, R. 2004. Self-enforcing climate change treaties. Proceedings of the National Academy of Sciences of the United States, 101(14): 5174-5179.

Farrell, J., \& Simcoe, T. 2007. Choosing the rules for formal standardization. Paper presented at the Second Annual Conference on Institutional Foundations for Industry Self-Regulation, Harvard Business School, Boston, MA.

Furger, F. 1997. Accountability and systems of self-governance: The case of the maritime industry. Law \& Policy, 19(4): 445-476.

Furman, J., \& Stern, S. 2006. Climbing atop the shoulders of giants: The impact of institutions on cumulative research. Working Paper, Boston University/Kellogg School of Management.

Gunningham, N. 1995. Environment, self-regulation, and the chemical industry: Assessing Responsible Care. Law and Policy, 17 (1): 57-108. 
Hardin, G. 1968. The tragedy of the commons. Science, 162(3859): 1243-1248.

Harhoff, D., \& Mayrhofer, P. 2007. User communities and hybrid innovation processes:

Theoretical foundations and implications for policy and research. Paper presented at the Second Annual Conference on Institutional Foundations for Industry Self-Regulation, Harvard Business School, Boston, MA.

Hart, S. 1995. A natural resource-based view of the firm. Academy of Management Review, 20: 986-1014.

Hill, J., \& Schneeweis, T. 1983. The effect of Three Mile Island on electric utility stock-prices: A note. Journal of Finance, 38(4): 1285-1292.

Hoffman, A.J. 1999. Institutional evolution and change: Environmentalism and the US chemical industry. Academy of Management Journal, 42(4): 351-371.

Hoffman A.J. 2001. Linking organizational and field-level analyses - The diffusion of corporate environmental practice. Organization \& Environment 14(2): 133-156.

Hoffman, A.J., \& Ocasio, W. 2001. Not all events are attended equally: Toward a middle-range theory of industry attention to external events. Organization Science, 12(4): 414-434.

Howard, J., Nash, J., \& Ehrenfeld, J. 2000. Standard or smokescreen? Implementation of a voluntary environmental code. California Management Review, 42(2): 63-82.

Ingram, P. \& K. Clay. 2000. The choice-within-constraints new institutionalism and implications for sociology. Annual Review of Sociology, 26: 525-546.

Jarrell, G., \& Peltzman, S. 1985. The impact of product recalls on the wealth of sellers. Journal of Political Economy, 93(3): 512-536. 
Jiang, R.H.J., \& Bansal, P. 2003. Seeing the need for ISO 14001. Journal of Management Studies, 40(4): 1047-1067.

Khanna, M. 2001. Non-mandatory approaches to environmental protection. Journal of Economic Surveys, 15(3): 291-324.

King, A.A., \& Lenox, M.J. 2000. Industry self-regulation without sanctions: The chemical industry's Responsible Care program. Academy of Management Journal, 43(4): 698716.

King, A.A., \& Lenox, M.J. 2001. Lean and green? An empirical examination of the relationship between lean production and environmental performance. Production and Operations Management, 10(3): 244-256.

King, A.A., Lenox, M.J., \& Barnett, M. 2002. Strategic responses to the reputation commons problem. In A.J. Hoffman \& M.J. Ventresca (eds.), Organizations, Policy and the Natural Environment: Institutional and Strategic Perspectives: 393-406. Stanford, CA: Stanford University Press.

King, A.A., Lenox, M.J., \& Terlaak, A.K. 2005. The strategic use of decentralized institutions: Exploring certification with the ISO 14001 management standard. Academy of Management Journal, 48(6): 1091-1106.

Lenox, M. 2006. The role of private, decentralized institutions in sustaining industry selfregulation. Organization Science, 17(6): 677-690.

Lenox, M., \& Nash, J. 2003. Industry self-regulation and adverse selection: A comparison across four trade association programs. Business Strategy and Environment, 12(6): 343-356. 
Lloyd, W.F. 1833. Two Lectures on the Checks to Population. Oxford, England: Oxford University Press. (Reprinted in Hardin, G. (ed.). 1964. Population, Evolution, and Birth Control: A Collage of Controversial Readings. San Francisco: W. H. Freeman.)

Lyon, T.P., \& Maxwell, J.W. 2007. Public voluntary programs reconsidered. Working Paper, Indiana University Kelley School of Business.

Marimon Viadiu, F., Casadesús Fa, M, \& Heras Saizarbitoria, M. 2006. ISO 9000 and ISO 14000 standards: An international diffusion model. International Journal of Operations \& Production Management, 26(1-2): 141-165.

Mattoo, A., \& Singh, H.V. 1994. Eco-labeling: Policy considerations. Kyklos, 47: 53-65.

Maxwell, J.W., Lyon, T.P., \& Hackett, S.C. 2000. Self-regulation and social welfare: The political economy of corporate environmentalism. Journal of Law \& Economics, 43(2): 583-617.

Melnyk, S.A., Sroufe, R.P., \& Calantone, R.J. 2003. A model of site-specific antecedents of ISO 14001 certification. Production and Operations Management, 12(3): 369-385.

Nash, J., \& Ehrenfeld, J. 1997. Codes of environmental management practice: Assessing their potential as a tool for change. Annual Review of Energy and the Environment, 22: 487535.

Neumayer, E., \& Perkins, R. 2004. What explains the uneven take-up of ISO 14001 at the global level? A panel-data analysis. Environment and Planning A, 36(5): 823-839.

North, D.C. 1991. Institutions. Journal of Economic Perspectives, 5(1): 97-112.

Ostrom, E. 1990. Governing the Commons: The Evolution of Institutions for Collective Action. Cambridge: Cambridge University Press. 
Ostrom, E. 1998. A behavioral approach to the rational choice theory of collective action. American Political Science Review, 92(1): 1-22.

Ostrom, E., Gardner, R., \& Walker, J. 1994. Rules, Games, and Common-Pool Resources. Ann Arbor, MI: University of Michigan Press.

Porter, M.E., \& van der Linde, C. 1995. Toward a new conception of the environmentcompetitiveness relationship. Journal of Economic Perspectives, 9(4): 97-118.

Potoski, M., \& Prakash, A. 2005a. Covenants with weak swords: ISO 14001 and facilities' environmental performance. Journal of Policy Analysis and Management, 24(4): 745769.

Potoski, M., \& Prakash, A. 2005b. Green clubs and voluntary governance: ISO 14001 and firms' regulatory compliance. American Journal of Political Science, 49(2): 235-248.

Rees, J. 1994. Hostages of Each Other: The Transformation of Nuclear Safety since Three Mile Island. Chicago: University of Chicago Press.

Rees, J. 1997. Development of communitarian regulation in the chemical industry. Law and Policy, 19: 477-528.

Reinhardt, F.L. 2000. Down to Earth: Applying Business Principles to Environmental Management. Boston: Harvard Business School Press.

Reinhardt, F.L., \& Vietor, R.H.K. 1996. Business Management and the Natural Environment: Cases and Text. Cincinnati: Southwestern Publishing Company.

Rivera, J. 2004. Institutional pressures and voluntary environmental behavior in developing countries: Evidence from the Costa Rican hotel industry. Society \& Natural Resources, 17(9): 779-797. 
Rivera, J., \& de Leon, P. 2004. Is greener whiter? Voluntary environmental performance of western ski areas. Policy Studies Journal, 32(3): 417-437.

Rivera, J., \& de Leon, P. 2005. Chief executive officers and voluntary environmental performance: Costa Rica's certification for sustainable tourism. Policy Sciences, 38(2-3): 107-127.

Rivera, J., de Leon, P., \& Koerber, C. 2006. Is greener whiter yet? The sustainable slopes program after five years. Policy Studies Journal, 34(2): 195-221.

Roberts, P.W., \& Greenwood, R. 1997. Integrating transaction cost and institutional theories: Toward a constrained-efficiency framework for understanding organizational design adoption. Academy of Management Review, 22(2): 346-373.

Schlager, E. 2002. Rationality, cooperation, and common pool resources. The American Behavioral Scientist, 45(5): 801-821.

Schlager, E., \& Ostrom, E. 1992. Property-rights regimes and natural resources: A conceptual analysis. Land Economics, 68(3): 249-262.

Shin, S. 2005. The role of the government in voluntary environmental protection schemes: The case of ISO 14001 in China. Issues \& Studies, 41(4): 141-173.

Short, J.L., \& Toffel, M.W. 2007. Coerced confessions: Self-policing in the shadow of the regulator. Journal of Law, Economics and Organization (forthcoming).

Stigler, G. J. 1989. Two notes on the Coase theorem. Yale Law Journal, 99(3): 631-633.

Teisl, M.F., Roe, B., \& Hicks, R.L. 2002. Can eco-labels tune a market? Evidence from dolphinsafe labeling. Journal of Environmental Economics \& Management, 43(3): 339-359. 
Tejeda-Cruz, C., \& Sutherland, W.J. 2004. Bird responses to shade coffee production. Animal Conservation, 7: 169-179.

Terlaak, A.K. 2007. Order without law: The role of certified management standards in shaping socially desired firm behaviors. Academy of Management Review (forthcoming).

Terlaak, A.K., \& King, A.A. 2006. The effect of certification with the ISO 9000 Quality Management Standard: A signaling approach. Journal of Economic Behavior and Organization, 60(4): 579-602.

Toffel, M.W. 2006. Resolving information asymmetries in markets: The role of certified management programs. Working Paper, Harvard Business School.

United Nations Environment Programme (UNEP). 2002. GEO: Global Environment Outlook 3. London: Earthscan Publications Ltd.

Welch, E.W., Mori, Y., \& Aoyagi-Usui, M. 2002. Voluntary adoption of ISO 14001 in Japan: Mechanisms, stages, and effects. Business Strategy and the Environment, 10(1): 43-62.

Williamson, O.E. 1985. The Economic Institutions of Capitalism: Firms, Markets, Relational Contracting. New York: The Free Press.

Worldwatch Institute. 2006. Vital Signs 2006-2007: The Trends that Are Shaping Our Future. New York: W. W. Norton. 